Žižek and Communist Strategy 



\section{ŽIŽEK AND COMMUNIST STRATEGY}

\section{ON THE DISAVOWED FOUNDATIONS OF GLOBAL CAPITALISM}

$\infty$

Chris McMillan 
(C) Chris McMillan, 2012, 2013

First published in hardback in 2012 by

Edinburgh University Press Ltd

22 George Square, Edinburgh EH8 9LF

www.euppublishing.com

This paperback edition 2013

Typeset in 11/13 Sabon by

Servis Filmsetting Ltd, Stockport, Cheshire, and printed and bound in Great Britain by CPI Group (UK) Ltd, Croydon CR0 4YY

A CIP record for this book is available from the British Library

ISBN 9780748646647 (hardback)

ISBN 9780748682331 (paperback)

ISBN 9780748646654 (webready PDF)

ISBN 9780748655496 (epub)

The right of Chris McMillan to be identified as author of this work has been asserted in accordance with the Copyright, Designs and Patents Act 1988 and the Copyright and Related Rights Regulations 2003 (SI No. 2498).

The author would like to thank the editors of The International Journal of Žižek Studies for allowing the reproduction of sections of 'The Communist Hypothesis; Žižekian Utopia or Utopian Fantasy?', originally published in vol. 5, no. 2, 2011. 